Egyptian

Orthodontic Journal

\title{
INFLUENCE OF TOPICAL FLUORIDE TREATMENT ON THE MECHANICAL PROPERTIES AND SURFACE TOPOGRAPHY OF TRANSLUCENT COMPOSITE ORTHODONTIC WIRE
}

\author{
Essam E. Al-Wakeel", Shaza M. Hammad,** \\ El-Sayed Gad ${ }^{* * *}$
}

ABSTRACT :

Objective: The aim of this study was to determine the effects of a fluoride prophylactic agent on the mechanical properties and surface quality of a preformed round translucent composite archwire comparing it with a nickel-titanium and a multistranded stainless steel wires.

Materials and Methods: The wires were immersed in either an acidulated fluoride solution (APF) or distilled water (control) for 1.5 hours at $37^{\circ} \mathrm{C}$. Flexural modulus of elasticity (E) and yield strength (YS) of the wires were measured using a 3-point bending test in a Universal Testing Machine. Springback ratio (YS/E) was calculated for each wire. The influence of fluoride treatment on properties of the wires was statistically analyzed using a student's $t$-test at $\alpha=0.05$. Surface changes were observed with a scanning electron microscope.

Results: Fluoride treatment produced a statistically significant reduction in $\mathcal{E}, Y S$ and $X S / E$ of the composite wire $(\mathscr{P}<0.05)$. In addition, a significant decrease in $\mathcal{E}$ of $\mathcal{N} i-T_{i}$ wire was found after exposure to fluoride, comparing it with distilled water control

\footnotetext{
* Associate Professor, Department of Dental Biomaterials, Faculty of Dentistry, Mansoura University.

${ }^{* *}$ Lecturer, Department of Orthodontics, Faculty of Dentistry, Mansoura University.

${ }^{* * *}$ Lecturer, Department of Dental Biomaterials, Faculty of Dentistry, Mansoura University.
} 
Egyptian

Orthodontic Journal

treatment. On the other hand, no significant effect of fluoride treatment was found on XS and XS/E of $\mathcal{N i} i$ Ti wire and also on the studied properties of the multistranded stainless steel wire $(p>0.05)$. Corrosive changes in surface topography were observed after exposure to the fluoride agent, which were more pronounced with the composite wire.

Conclusions: The results suggest that using topical fluoride agent with translucent composite wire could decrease mechanical properties and might damage surface of the wire, which potentially contribute to prolonged orthodontic treatment.

\section{INTRODUCTION}

Direct bonding system has been considered as one of the most significant developments in clinical orthodontics. Today, multibracket appliances are widely used and better mechanical properties of these appliances have been emphasized. Orthodontic brackets are usually made of stainless steel. However, the quality of plastic or ceramic brackets has recently been improved, and the use of such esthetic brackets is becoming more popular. Many studies ${ }^{1-3}$ have been carried out on these esthetic brackets to improve their mechanical properties.

The archwire, which is one of the main parts of a multibracket appliance, is designed to move teeth from malocclusion to a preferred dental occlusion through mechanical interaction with the bracket slots. Dental arch alignment and leveling is the initial stage of orthodontic treatment. Satisfactory completion of this stage is essential if esthetics, function and stability are to be achieved. Ideally, in that vital stage, the wire should generate a continuous light force, over a prolonged period of time. ${ }^{4,5}$ Knowledge of the mechanical properties of such wires is very helpful to the clinician in design and application of optimal force systems during orthodontic treatment. ${ }^{6}$ Although the type of the wires most frequently recommended for this first stage is superelastic nickeltitanium, ${ }^{5}$ some technicians still prefer multistranded stainless steel archwires as they are cheaper and as clinically effective as nickel-titanium wires. ${ }^{4,7}$ 
With the steady increase in the number of adults undergoing orthodontic treatment, there is a demand for more esthetic orthodontic appliances. ${ }^{8}$ The development of orthodontic appliances and materials with acceptable esthetics for the patient and optimal technical performance for the orthodontist has been an extremely essential goal. ${ }^{9}$ Two kinds of archwire have been produced to improve esthetics. One is a metal wire with white-colored Teflon (polytetrafluoroethylene) or epoxy resin on the surface. The other type is made from translucent composite materials using a polymer for the matrix and glass fibers for reinforcement. ${ }^{10}$ It has been suggested that these wires are not only high esthetics but also have mechanical properties similar to those of metal wires. ${ }^{11}$ A recent introduction into the market, the BioMers translucent archwire, has been developed especially as an initial leveling and aligning wire. This wire is manufactured by a patented polymer composite fabrication process. It is comprised of glass fibers as reinforcement and a polymer resin as the matrix. The glass fibers provide the necessary stiffness to straighten teeth, while the translucent polymer resin ensures the wire is not clearly visible when in use. Together with the flexibility of the fabrication technology, wires of differing strength and stiffness can be engineered by varying the reinforcement level without compromising functionality. Fiber-reinforced composites are regarded as the last great frontier of orthodontic materials.

One of the most important components of successful orthodontic treatment is the maintenance of good oral hygiene and caries control. Compromised oral hygiene can lead to enamel demineralization and decay. ${ }^{12,13}$ Daily topical fluoride is commonly prescribed by orthodontists to guard against this complication. ${ }^{14}$ Acidulated phosphate fluorides (APF), have been used extensively to prevent demineralization or remineralization of white spot lesions around orthodontic brackets. However, the fluoride ions in the prophylactic agents have been reported to cause corrosion, discoloration of and alteration of the mechanical properties of metallic wires, particularly when the passivated wire surfaces break because of mechanical friction between brackets and 
wires. ${ }^{15,16}$ To date, the effects of prophylactic fluoride agents on the mechanical properties of the translucent composite archwire have not been reported. The purpose of this study was to evaluate the effects of a fluoride prophylactic agent on the mechanical properties and surface topography of a translucent composite wire compared with $\mathrm{Ni}-\mathrm{Ti}$ and multistranded stainless steel wires.

\section{MATERIALS AND METHODS}

Three types of commercially available round orthodontic archwires were investigated in this study. These wires were a preformed translucent composite (Translucent Archwire, BioMers Products, LLC, FL, USA), Ni-Ti (Super Elastic NiTi, The International Orthodontic Services, Inc., TX, USA.) and multistranded stainless steel, (Tricat, GAC International, NY, USA). A full description of these wires is presented in Table 1. Each wire specimen was 0.16 in diameter x $25 \mathrm{~mm}$ length, cut from the straight portion of the preformed archwires. Twenty specimens were cut from each type of wire with a total of sixty specimens. For each type of wire, ten specimens were incubated at $37^{\circ} \mathrm{C}$ in distilled water (control treatment), while the other ten were incubated in a prepared fluoride solution $(1.1 \%$ acidulated phosphate fluoride $[\mathrm{APF}], 0.5 \% \mathrm{w} / \mathrm{v}$ fluoride, $\mathrm{pH}=5.1$ ) for 1.5 hours. $^{17}$

Before testing, the specimens were removed from the perspective solutions and rinsed with distilled water. The diameter of all wires was determined with an electronic caliper (Mitutoyo, Tokyo, Japan) with an accuracy of $0.001 \mathrm{~mm}$. All specimens were subjected to a 3-point bending test, as described by Miura et al. ${ }^{5}$ and modified by Krishnan and $\mathrm{Kumar}^{18}$, on a Universal Testing Machine (Model LRX-plus; Lloyd Instruments Ltd., Fareham, UK) with a load cell of $5 \mathrm{kN}$. The setup included a specially constructed fixture comprising of two poles placed 12 $\mathrm{mm}$ apart on a stage attached to the lower jaw of the machine. Compressive force was applied at a crosshead speed of $0.5 \mathrm{~mm} / \mathrm{min}$ by means of a steel rod with bibevelled chisel end placed in the midway between the two poles. Each specimen was loaded to a deflection of $3.1 \mathrm{~mm}$. Load in newtons and deflection in millimeter were recorded for each specimen with a computer software program (Nexygen-MT; Lloyd 
Egyptian

Orthodontic Journal

Instruments Ltd). Based upon the load-deflection curve and the dimensions of the specimen, flexural stress as a function of flexural strain was determined for each specimen. Flexural modulus of elasticity (E) and yield strength (YS) were calculated for each specimen. Springback ratio (YS/E) was calculated for each specimen by dividing yield strength by modulus of elasticity. The influence of fluoride treatment on properties of the wires was statistically analyzed using a student's t-test at $\alpha=0.05$. The statistical calculations were performed using SPSS (Version 17) software program (SPSS Inc; Chicago, IL, USA).

One representative wire was randomly selected from each wire/experimental condition for scanning electron microscopy (SEM) analysis to characterize the topography of the wire surface. After gold coating of the translucent composite wire, the specimens were mounted with double-sided conductive carbon tape and carbon paint on aluminum SEM stubs and examined using a SEM (Philips XL3-Philips, North Billerica, Massachusetts USA) at 1000x magnification.

Table 1. Orthodontic wires used in the study.

\begin{tabular}{|c|c|c|c|c|}
\hline Wire & $\begin{array}{c}\text { Wire size and } \\
\text { brand }\end{array}$ & Composition & Manufacturer & Batch \# \\
\hline $\begin{array}{l}\text { Translucent } \\
\text { composite }\end{array}$ & $\begin{array}{l}0.016 \text { in } \\
\text { Translucent } \\
\text { Archwire }\end{array}$ & $\begin{array}{l}\text { Mixture of cured } \\
\text { copolymers, Bis- } \\
\text { EMA, TEGDMA, } \\
\text { and glass fibers. }\end{array}$ & $\begin{array}{l}\text { BioMers } \\
\text { Products, LLC, } \\
\text { FL, USA. }\end{array}$ & 080919 \\
\hline Nickel-titanium & $\begin{array}{l}0.016 \text { in Super } \\
\text { Elastic NiTi } \\
\text { wire }\end{array}$ & $\begin{array}{l}52 \% \mathrm{Ni}, 45 \% \mathrm{Ti} \\
\text { and } 3 \% \mathrm{Co} .\end{array}$ & $\begin{array}{l}\text { The International } \\
\text { Orthodontic } \\
\text { Services, Inc., } \\
\text { TX, USA. }\end{array}$ & 067392 \\
\hline $\begin{array}{l}\text { Multistranded } \\
\text { stainless steel }\end{array}$ & $\begin{array}{l}0.016 \text { in Tricat } \\
\text { wire }\end{array}$ & $\begin{array}{l}71 \% \mathrm{Fe}, 17-20 \% \\
\mathrm{Cr}, 8-12 \% \mathrm{Ni} \text { and } \\
0.15 \mathrm{C} \text {. }\end{array}$ & $\begin{array}{l}\text { GAC } \\
\text { International, } \\
\text { NY, USA. }\end{array}$ & 0301633 \\
\hline
\end{tabular}

Volume 38-December 2010 
Egyptian

Orthodontic Journal

\section{RESULTS}

Mean elastic modulus, yield strength, springback ratio, standard deviations and results of t-tests of the studied wires after immersion in distilled water and APF solution are presented in Table 2. A graphical presentation of the results of springback ratio is shown in Figure 1. Fluoride treatment produced a statistically significant decrease in E, YS and YS/E of the composite wire, comparing it with distilled water control treatment $(\mathrm{p}<0.05)$. In addition, fluoride treatment gave a significant reduction in $\mathrm{E}$ of $\mathrm{Ni}-\mathrm{Ti}$ wire. On the other hand, no significant effect of fluoride treatment was found on YS and YS/E of Ni-Ti wire ( $p>0.05)$. In addition, fluoride treatment had no significant effect on the studied properties of the multistranded stainless steel wire $(p>0.05)$.

Representative scanning electron photomicrographs of the studied wires exposed to distilled water and APF solution are shown in Figure 2. The observations indicated that some surface changes occurred on the surface of the wires after immersion in APF agent. In particular, composite wire demonstrated dramatic changes in the surface morphology. In distilled water treatment, the wire surface appears homogenous with little irregularities. In contrast, fluoride treatment produced inhomogenous surface with more irregularities and some surface damage, suggesting a loss of surface material. The SEM images of $\mathrm{Ni}$-Ti wire exposed to distilled water showed some dark areas which might be by-products of the manufacturing process. After fluoride treatment, the surface had a mottled, slightly pitted appearance with some bright-white spots which may result from the action of fluoride. As compared to the distilled water control wire, following exposure to AFP, stainless steel wire surface appeared rougher and the cracks along the wrought structure were more prevalent and more accentuated, indicating some surface corrosive effects. 
Table 2. Mean values, standard deviations and results of t-test of mechanical properties of the studied wires after exposure to distilled water or fluoride solution.

\begin{tabular}{llccc}
\hline Wire & Treatment & $\begin{array}{c}\text { Mean flexural } \\
\text { modulus of elasticity } \\
(\mathbf{G P a} \pm \mathbf{S D}\end{array}$ & $\begin{array}{c}\text { Mean yield } \\
\text { strength } \\
\mathbf{( M P a}) \pm \text { SD }\end{array}$ & $\begin{array}{c}\text { Springback } \\
\text { ratio } \\
\left(\mathbf{1 0}^{-3} \mathbf{)} \pm \mathbf{S D}\right.\end{array}$ \\
\hline $\begin{array}{l}\text { Translucent } \\
\text { composite }\end{array}$ & $\begin{array}{l}\text { Distilled water } \\
\text { (control) }\end{array}$ & $37.5 \pm 2.0$ & $594.9 \pm 17.0$ & $15.9 \pm 0.7$ \\
& Fluoride & $34.7 \pm 2.4^{*}$ & $504.4 \pm 15.8^{*}$ & $14.6 \pm 1.2^{*}$ \\
& & $\mathrm{t}=3.045$ & $\mathrm{t}=12.430$ & $\mathrm{t}=2.862$ \\
& $\mathrm{p}=0.014$ & $\mathrm{p}=0.0001$ & $\mathrm{p}=0.019$ \\
\hline Nickel-titanium & $\begin{array}{l}\text { Distilled water } \\
\text { (control) }\end{array}$ & $68.2 \pm 3.5$ & $1007.1 \pm 37.5$ & $15.1 \pm 1.1$ \\
& Fluoride & $63.1 \pm 6.5^{*}$ & $990.7 \pm 47.2$ & $15.9 \pm 2.0$ \\
& & $\mathrm{t}=3.160$ & $\mathrm{t}=1.052$ & $\mathrm{t}=1.029$ \\
& $\mathrm{p}=0.012$ & $\mathrm{p}=0.320$ & $\mathrm{p}=0.330$ \\
\hline $\begin{array}{l}\text { Multistranded } \\
\text { stainless steel }\end{array}$ & $\begin{array}{l}\text { Distilled water } \\
\text { (control) }\end{array}$ & $105.8 \pm 7.3$ & $1092.0 \pm 26.2$ & $10.4 \pm 0.8$ \\
& Fluoride & $104.2 \pm 7.7$ & $1082.9 \pm 28.5$ & $10.3 \pm 0.9$ \\
& & $\mathrm{t}=0.665$ & $\mathrm{t}=1.792$ & $\mathrm{t}=0.314$ \\
& $\mathrm{p}=0.522$ & $\mathrm{p}=0.107$ & $\mathrm{p}=0.761$ \\
\hline
\end{tabular}

* Significantly different from control, $\mathrm{p}<0.05$.

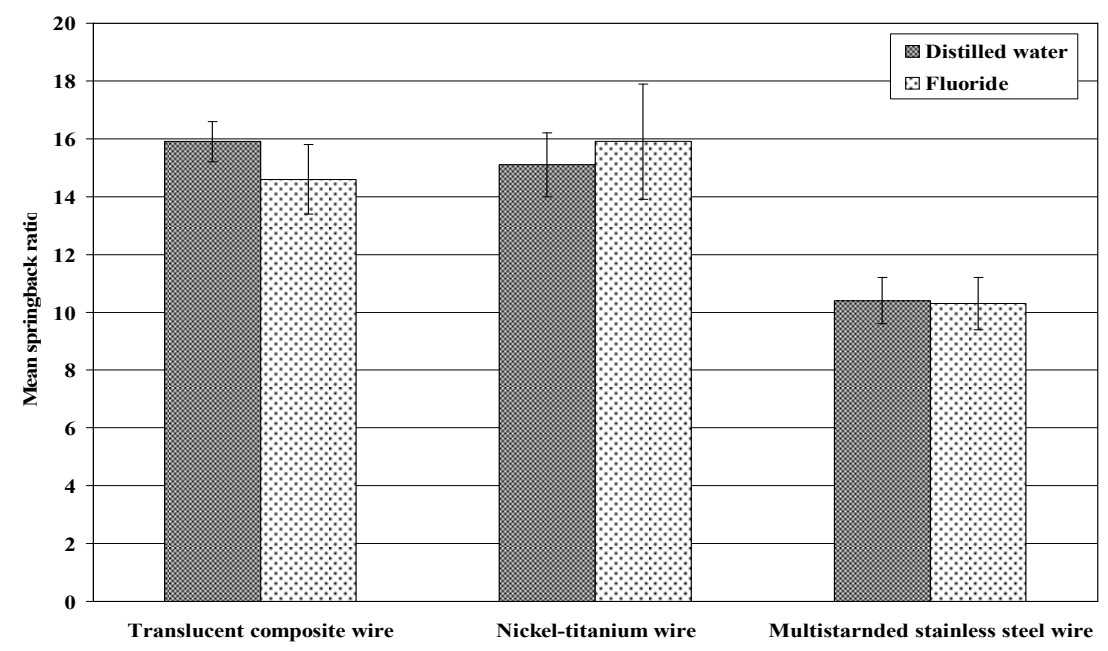

Figure 1. Mean springback ratio (YS/E) and standard deviations of the studied wires after immersion in distilled water and fluoride solution. 
Egyptian

Orthodontic Journal
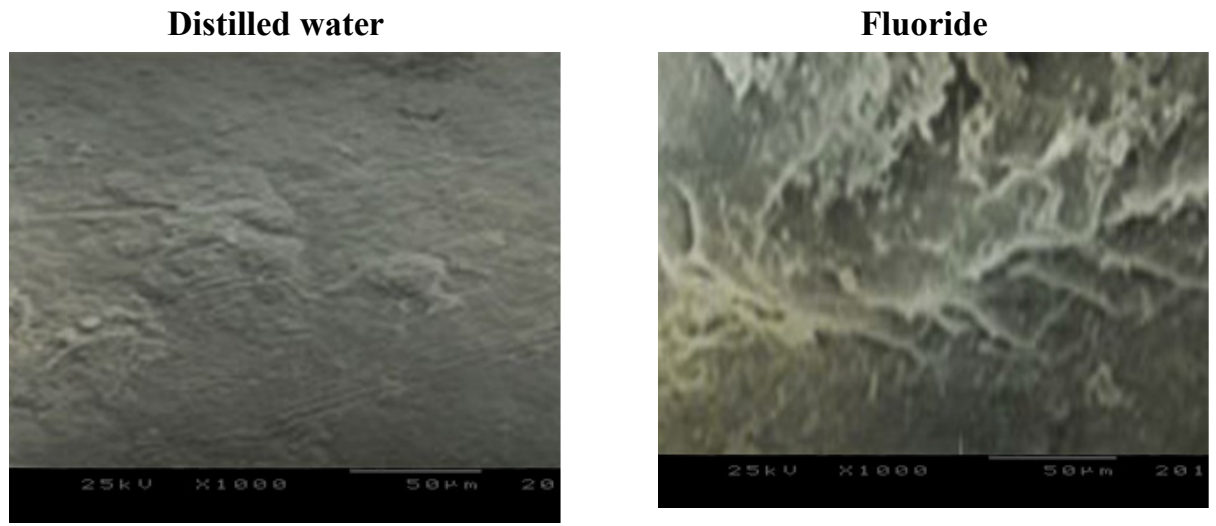

Translucent composite wire
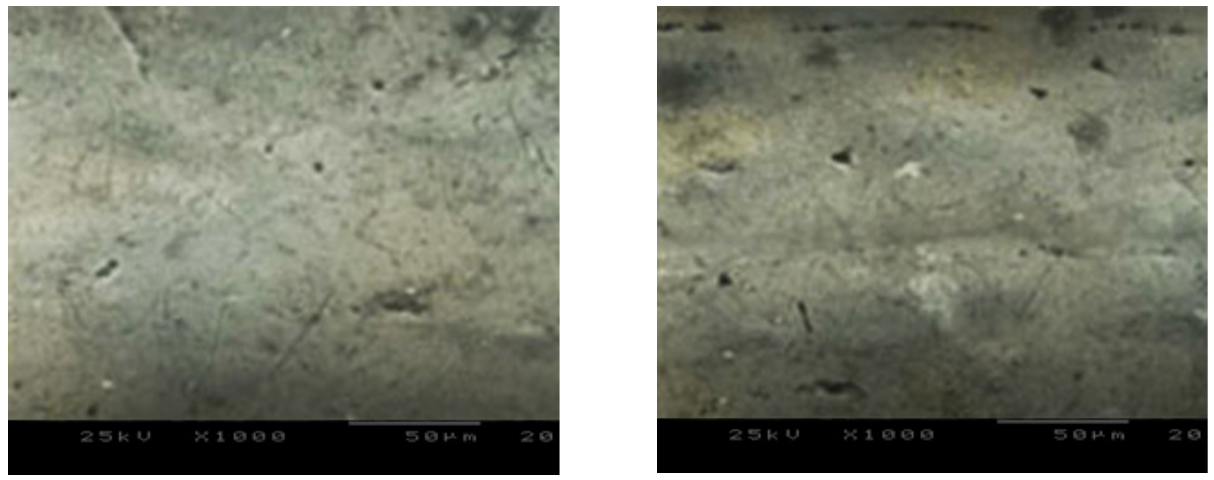

Nickel-titanium wire
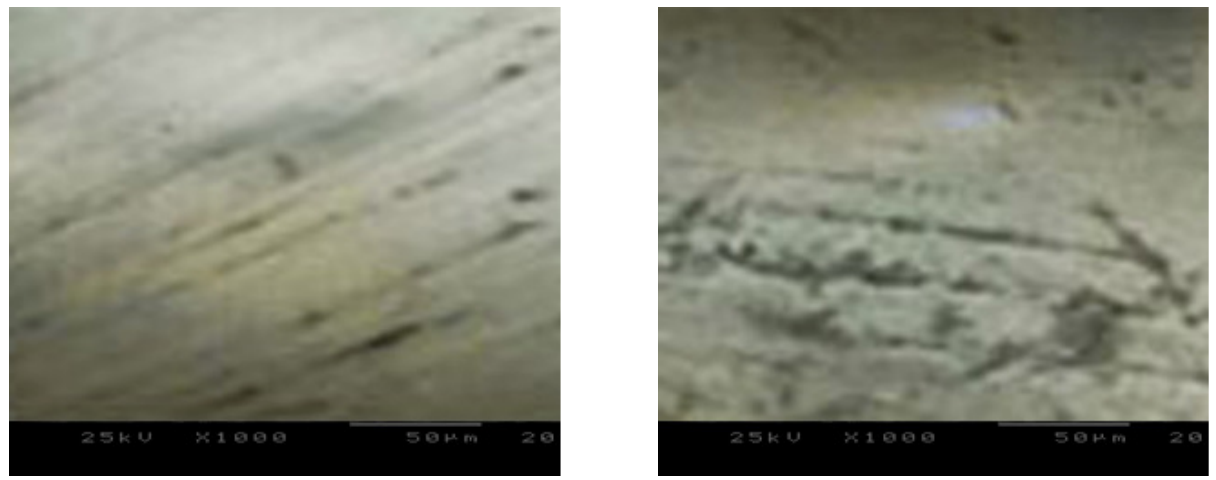

Multistranded stainless steel wire

Figure 2. Representative SEM images of translucent composite, Nickel-titanium and multistranded stainless steel wires exposed to distilled water and fluoride solution (1000x magnification).

Volume 38-December 2010 
Egyptian

Orthodontic Journal

\section{DISCUSSION}

One of the disadvantages of direct bonding is that enamel demineralization can occur around orthodontic brackets. Because fluoride enhances the potential for remineralization, use of topical fluoride preparations during orthodontic treatment has been advocated. ${ }^{19,20}$ In Vitro studies ${ }^{15,17}$ have reported the deleterious effects of fluoride agents on the mechanical properties of metallic orthodontic wires. Currently, fiber-reinforced polymer composites are being developed for use as orthodontic archwire materials. These wires can be manufactured in a wide range of clinically relevant levels of elasticity, allowing practitioners to use variable-modulus orthodontic techniques without having to change archwire. Allergic reactions to nickel, which are a debatable concern for many metallic alloys, are also averted with composite materials. The current in vitro study evaluated the effect of fluoride treatment on mechanical properties and surface quality of a translucent fiber-reinforced composite wire, comparing it with the most frequently used archwires for the first stage of orthodontic treatment. The wires were exposed to distilled water and APF solution for $1.5 \mathrm{~h}$. This exposure time would be equivalent to 3 months of $1 \mathrm{~min}$ daily topical fluoride applications as stated by Walker and White in 2005. ${ }^{17}$ Flexural modulus of elasticity (E) and yield strength (YS) were determined for each wire. The ratio YS/E is considered to be a very useful index of wire performance. ${ }^{21}$ This ratio indicates the clinical performance of the wire in terms of load-deflection rate, working range, stiffness, and resilience.

The findings of the present study indicated that fluoride treatment produced a statistically significant decrease in E, YS and YS/E of the composite wire. This could be attributed to the deteriorating effect of the acidic fluoride on the glass filler present in the composite wire. This was in correspondence with what has been observed in the SEM images (Fig. 2) that show damage of the surface of the wire after exposure to fluoride solution. This observation goes with the results of previous studies ${ }^{22,23}$, which also found that topical application of APF gels might damage surfaces of composites with glass filler particles. In addition, acidic fluoride regimes, such as acidulated phosphate fluoride may lead to increased surface roughness of resin composite materials. ${ }^{24}$ It has been

Volume 38-December 2010 
Egyptian

Orthodontic Journal

found that glass particles are more prone to stress corrosion when exposed to media of high or low $\mathrm{pH}$, whereas pure silica fillers are less affected by acidic media. ${ }^{25}$ Additionally to this direct influence of the acidic media on the fillers, fluoride may cause depolymerization of the matrix-filler interface and support filler loss from the matrix as reported by Bowen and Cleek. $^{26}$

The results of the present study found a significant decrease in flexural modulus of the Ni-Ti wire after fluoride treatment compared with the distilled water control treatment. This is probably because of the corrosive effect of the topical fluoride on titanium-based orthodontic wires. These findings go with the results of previous studies ${ }^{17,27}$, which suggested that fluoride adversely affect mechanical properties of $\mathrm{Ni}-\mathrm{Ti}$ wires. The degradation and loss of the oxide film on the surface expose the underlying alloy, leading to corrosion and absorption of hydrogen ions from the aqueous-based solution because of the high affinity of titanium with hydrogen. ${ }^{28}$ Hydrogen absorption and associated embrittlement of titanium-based alloys have been explained by the diffusion of hydrogen through interstitial sites, dislocations, and grain boundaries reacting with lattice atoms to form hydride phases, particularly titanium hydride. Titanium hydrides have been reported to form a body-centered tetragonal structure, considered to be the cause of the related degradation of the alloy's mechanical properties. ${ }^{29}$

Comparing with the studied wires, the apparent lack of fluoride effect on mechanical properties multistranded stainless steel wire could be related to its elemental composition, where chromium and nickel imparts corrosion resistance. The chromium contributes to the surface oxide layer, which spontaneously undergoes passivation and repassivation in air and the oral environment. The nickel aids corrosion resistance by competing with the chromium to form salts, making more chromium available for passivation. These findings coincide with the results a previous study ${ }^{30}$ which found that stainless steel is less susceptible to corrosion in a fluoridated acidic environment compared with nickel-titanium. In addition, multistranded stainless steel wires are composed of specified number of thin wire sections coiled around each other. This could be 
another contributing factor regardless of the corrosive changes that seen in the SEM images (Fig. 2).

The results of the present in vitro study demonstrated the deleterious effects of fluoride agent on the mechanical properties of the translucent composite wire. However, the wires were exposed to fluoride agent continuously for $1.5 \mathrm{~h}$. In clinical situation, fluoride exposure would be repeated shorter exposures rather than a continuous exposure. So a future study is needed to investigate cumulative fluoride exposure based on shorter, repeated treatments on the mechanical properties of orthodontic wires.

\section{CONCLUSIONS}

Based on the results and within the limitations of this study, the following conclusions could be drawn:

1. Topical fluoride agent significantly decreased mechanical properties of the translucent composite wire and might damage surface of the wire, which potentially contribute to prolonged orthodontic treatment.

2. Nickel-titanium wire showed significant decrease in flexural modulus of elasticity after exposure to fluoride solution. In contrast, fluoride had no significant effect on the mechanical properties of multistranded stainless steel wire.

\section{REFERENCES}

1. Chaconas SJ, Caputo AA, Niu S-L. Bond strength of ceramic brackets with various bonding systems. Angle Orthod 1991;61:35-42.

2. Rhodes RK, Duncanson MG, Nanda RS, Currier GF. Fracture strengths of ceramic brackets subjected to mesial-distal arch wire tipping forces. Angle Orthod 1992;62:67-76.

3. De Franco DJ, Spiller RE, von Fraunhofer JA. Frictional resistances using Teflon-coated ligatures with various bracket-arch wire combinations. Angle Orthod 1995;65:63-72.

4. Jones ML, Staniford H,Chan C. Comparison of superelastic Ni Ti and multistranded stainless steel wires in initial alignment. J Clinc Orthod 1990;24:611-613. 
5. Miura F, Mogi M, Ohura Y, Hamanaka H. The super-elastic property of the Japanese Ni Ti alloy wire for use in Orthodontics. Am J Orthod Dentofacial Orthop 1986;90:1-10.

6. Juvvadi SR, Kailasam V, Padmanabhan S, Chitharanjan AB. Physical, mechanical, and flexural properties of 3 orthodontic wires: An in-vitro study. Am J Orthod Dentofacial Orthop 2010;138:623-630.

7. Quintao CC, Cal-Neto JP, Menez LC, Elias CN. Force deflection properties of initial orthodontic archwires. World J Orthod 2009;10:29-32.

8. Goldstein MC, Burns MH, Yurfest P. Esthetic orthodontic appliances for the adult. Dent Clin North Am 1989;33:183-193.

9. Bishara SE. Ceramic brackets and the need to develop national standards. Am J Orthod Dentofacial Orthop 2000;117:595-597.

10. Goldberg AJ, Burstone CJ. The use of continuous fiber reinforcement in dentistry. Dent Mater 1992;8:197-202.

11. Valiathan A, Dhar S. Fiber reinforced composite arch-wires in orthodontics: function meets esthetics. Trends Biomater Artif Organs 2006;20:16-19.

12. Gorelick L, Geiger AM, Gwinnett AJ. Incidence of white spot formation after bonding and banding. Am J Orthod 1982;81:93-98.

13. Thilander BL. Complications of orthodontic treatment. Curr Opin Dent 1992:28-37.

14. Alexander SA, Ripa LW. Effects of self-applied topical fluoride preparations in orthodontic patients. Angle Orthod 2000;70:424-430.

15. Watanabe I, Watanabe E. Surface changes induced by fluoride prophylactic agents on titanium-based orthodontic wires. Am J Orthod Dentofacial Orthop 2003;123:653-656.

16. Kao C-T, Huang T-H. Variations in surface characteristics and corrosion behaviour of metal brackets and wires in different electrolyte solutions. Eur J Orthod 2010;32:555-560. 
17. Walker MP, White RJ, Kulac KS. Effect of fluoride prophylactic agents on the mechanical properties of nickel-titanium-based orthodontic wires. Am J Orthod Dentofacial Orthop 2005;127:662-669.

18. KrishnanV, Kumar KJ. Mechanical properties and surface characteristics of three archwire alloys. Angle Orthod 2004;74:825-831.

19. Schmit J, Staley RN, Wefel JS, Kanellis M, Jakobsen JR, Keenan PJ. Effect of fluoride varnish on demineralization adjacent to brackets bonded with RMGI cement. Am J Orthod Dentofacial Orthop 2002;122:125-134.

20. Kim MJ, Lim B, Chang W, Lee Y, Rhee S, Yang H. Phosphoric acid incorporated with acidulated phosphate fluoride gel etchant effects on bracket bonding. Angle Orthod 2005;75:678-684.

21. Burstone CJ, Goldberg AJ. Maximum forces and deflections from orthodontic appliances. Am J Orthod Dentofacial Orthop 1983;84:95-103.

22. Kula K, McKinney JE, Kula TJ. Effects of daily topical fluoride gels on resin composite degradation and wear. Dent Mater 1997;13:305-511.

23. Papagiannoulis L, Tzoutzas J, Eliades G. Effect of topical fluoride agents on the morphologic characteristics and composition of resin composite restorative materials. J Prosthet Dent 1997;77:405-413.

24. Dionysopoulos P, Gerasimou P, Tolidis K. The effect of home-use fluoride gels on glass-ionomer, compomer and composite resin restorations. J Oral Rehabil 2003;30:683-689.

25. Mair LH, Krishnan VK. Three body wear studies of five dental composites preconditioned in food simulating media. Biomed Mater Eng 1999;9:145-149.

26. Bowen RL, Cleek GW. A new series of x-ray-opaque reinforcing fillers for composite materials. J Dent Res 1972;51:177-182.

27. Ramalingam A, Kailasam V, Padmanabhan S, Chitharanjan A. The effect of topical fluoride agents on the physical and mechanical properties of NiTi and copper NiTi archwires. An in vivo study. Aust Orthod J 2008;24:26-31. 
28. Yokoyama K, Kaneko K, Moriyama K, Asaoka K, Sakai J, Nagumo M. Hydrogen embrittlement of $\mathrm{Ni}-\mathrm{Ti}$ superelastic alloy in fluoride solution. J Biomed Mater Res 2003;65:182-187.

29. Wu SK, Wayman CM. Interstitial ordering of hydrogen and oxygen in TiNi alloys. Acta Metallurg 1988;36:1005-10013.

30. Schiff N, Dalard F, Lissac M, Morgon L, Grosgogeat B. Corrosion resistance on three orthodontic brackets: a comparative study of three fluoride mouthwashes. Eur J Orthod 2005;27:541-549. 